\title{
STUDY ON EFFECTIVENESS OF SHINKANSEN STATION CATCHMENT AREA: A CASE STUDY OF FUKUSHIMA SHINKANSEN STATION, JAPAN
}

\author{
KITTIPONG TISSAYAKORN ${ }^{1}$, FUMIHIKO NAKAMURA ${ }^{2}$, SHINJI TANAKA ${ }^{1}$, \\ RYO ARIYOSHI ${ }^{1} \&$ SHINO MIURA ${ }^{2}$ \\ ${ }^{1}$ Graduate School of Urban Innovation, Yokohama National University, Japan \\ ${ }^{2}$ Graduate School of Frontier Sciences, The University of Tokyo, Japan
}

\begin{abstract}
Transit-oriented development (TOD) in Thailand is the hot issue for mega-infrastructure projects, especially the high-speed rail project connecting Thailand's capital Bangkok to Nakhon Ratchasima province currently underway because TOD is a meaningful tool to promote and support sustainable development for the high-speed rail project. However, Thailand does not have the practical knowhow to make it happens. Nakhon Ratchasima high-speed rail hub is one of the high-speed rail stations in the high-speed rail project and representative of Thai high-speed rail station in terms of potential and necessity of development because of large gross provincial product (GPP), municipality size, travel distance from the origin, ridership, vacant land around the hub, and availability of feeder services. Meanwhile, Japan is a proven methodology among several countries and uses TOD as a strategy for sustainable development. Fukushima shinkansen station is the best practice and lesson learned for Nakhon Ratchasima high-speed rail hub on the basis of international comparison by type of station, size of station, travel distance, and travel time perspective. On top of that, not only the research problems in the TOD do not identify but also the high-speed rail/shinkansen station catchment areas do not take into account for the first year of operation. This research evaluates the size of the Fukushima shinkansen station catchment area by utilizing a dense network and land value approach and compares it with the existing works of academic literature. The results show Fukushima shinkansen station catchment areas are 12.4 and $17.6 \mathrm{~km}$ based on dense network and land value, respectively. This station catchment area is denser than only California cities because of the limitation of land that led to developing the urbanization. Meanwhile, the population factor and industry factor have a significant impact to drive the change in land value.
\end{abstract}

Keywords: dense network, high-speed rail/shinkansen station, international comparison, land value.

\section{INTRODUCTION}

Since Thailand is located a hub of land transport connectivity among the Association of Southeast Asian Nations countries, China and Thailand jointly desire to promote the strategic partnership through the memorandum of understanding on the cooperation on Thailand's railways infrastructure development on the strategic framework for the development of Thailand's transportation infrastructure 2015-2022. The high-speed rail project connecting Thailand's capital Bangkok to Nakhon Ratchasima province (the HSR project) is one of the significant implementations in long-term benefits under the strategic framework. The project will be done on a government-to-government basis.

The HSR project was approved by the Prayut cabinet in July 2017 and expected to operate in 2024. There were two main reasons why Thailand decided to invest in highspeed rail (HSR) development. The first reason was to support the strategy of development of the international railway network and the second reason was to boost the regional economic development along the corridor [1].

However, a feasibility study of the HSR project was not feasible. Because the direct economic return was $8.56 \%$ and financial return could not evaluate, therefore, they had lower than the benchmark in economics $(12 \%)$ and finance $(5 \%)$ based on the Office of the 
National Economic and Social Development Council criteria [2]. In other words, Thailand's government is facing how to drive it to sustainability in the long term.

A feasibility study recommended that if the government utilized the land development surrounding the HSR stations (or transit-oriented development (TOD)), an economic return would increase from $8.56 \%$ to $11.68 \%$ and approached a criterion [1]. TOD becomes one of the alternative strategies to boost economic value, but Thailand's government does not have the practical know-how and experience in how to make it happen. TOD had several elements such as station catchment area, policy, and legislation and regulation for construction [3].

This study is a part of the TOD strategy in the HSR project in Thailand and only focuses on the station catchment area. Previous research on station catchment areas focused primarily on urban transit stations and often defined a radius of 400-800 m from the stations [4], [5]. However, HSR/shinkansen station catchment areas differ from station catchment areas of urban transit and have larger accessibility because of inter-city travel [6]. The reasonable radius for the HSR/shinkansen station catchment areas fell in the radius range of 5-25 km based on feeder systems [7], [8]. There exists very limit research on the size of the HSR/shinkansen station catchment areas for the first year of operation. Hence, this study focuses on the size of the Japanese shinkansen station catchment area to identify the radius of the shinkansen station catchment area and recommend to apply and develop on Nakhon Ratchasima HSR station (hub) based on the lesson learned from the Fukushima shinkansen station (it will explain in Section 3 why this research selected the Fukushima shinkansen station as a case study).

The objectives of this research consist of twofold: (1) to evaluate the Fukushima shinkansen station catchment area for the first year of operation (or 1982) based on dense network and land value angle; and (2) to compare the Fukushima shinkansen station catchment area with the prior HSR/shinkansen station catchment areas. The hypotheses comprised of (1) what is relevant with the Fukushima shinkansen station catchment areas based on dense network and land value perspective?; and (2) which factors contribute to the Fukushima shinkansen station catchment area? This research only focuses on population and economic growth (change in the industry) on account of the limitation of information, as well as the floor area ratio, is assumed that it did not apply in Fukushima city in the initial year (1982-1986). !

\section{LITERATURE REVIEW}

\subsection{Transit-oriented development (TOD) concept}

TOD originated a new urbanism concept at a regional scale and formed a network of highdensity and mixed-use nodes of the developed link by transit corridors. New urbanists advocated in the USA to endeavor to go back to an older form of streetcar suburbs [9].

TOD was the heart of the strategy to reduce private vehicles and develop sustainability. The location of the transit stations supports the land use, while development would be increasing ridership by enhancing the land use, improving the convenience, and enhancing the users [10]. TOD was confirmed by many countries where applied it around the transit stations at the same time [11]-[15]. 


\subsection{HSR/shinkansen station catchment area}

The inter-city railway was defined as the express passenger train that serviced a longer distance than the commuter train and long-distance train but the limitation of transit stops. Consequently, HSR/shinkansen attributed an inter-city railway service that had a highly efficient and reliable communication system [11], [16], [17].

$\mathrm{HSR} / \mathrm{shinkansen} \mathrm{station} \mathrm{catchment} \mathrm{area} \mathrm{in} \mathrm{this} \mathrm{research} \mathrm{is} \mathrm{defined} \mathrm{as} \mathrm{the} \mathrm{zone} \mathrm{within} \mathrm{an}$ urban design that had a willingness to travel to and from the transit stations and the transportation modes available [17]. However, willingness to travel varies on the socioeconomic, purpose of the trip, and built environment. Therefore, the originality is to use primary feeder service which linked the hub because it is a connector and requires transportation modes to service the rail passengers.

The size of the geographical catchment area was created by a circle surface with a radius of the maximum travel distance. It influenced the travel demand to determine the ridership that used the hubs in different radius, as well as involved land value [15], [17]-[20]. The net benefit from the hubs depended on station characteristics, the income of the people, and the station catchment area [21].

\subsection{Accessibility}

Accessibility was defined as the ease with which people could reach destinations and activities [22]. Investment in transportation (high quality and efficiency) led to better accessibility of the area. This change in accessibility impacted land value and usage [23], [24].

The transportation systems not only enhanced the accessible range but also brought about more efficient land-use patterns for minimizing travel distance [25]. Therefore, travelers derive a good deal from the transportation systems that benefited from easier access to transportation modes.

\subsection{Land value (or land price)}

The land value was a fair market value of land, excluding buildings. Change in land value was the same way. The change was caused by population growth, economic development, public investment in infrastructure, change in land-use regulation, and landowner's investment. While the land value increased, the government applied the public financing method (land value capture) to solve this point [26].

Accessibility is an alternative approach to transportation systems and service evaluation. Not only increased land value but also land use has changed the result of increased accessibility. Consequently, the originality follows the above theory and utilizes the maximum average land value as an indicator to measure the station catchment area.

\section{INTERNATIONAL COMPARISON}

The HSR project consists of six HSR hubs, namely Bang Sue, Don Mueang, Ayutthaya, Saraburi, Pak Chong, and Nakhon Ratchasima. Bang Sue and Don Mueang HSR hub is located in the capital city of Thailand and others are placed in the regional areas.

This research merely focuses on five HSR hubs excluding Bang Sue HSR hub because Bang Sue HSR hub was studied in the feasibility study project [26]. In this research, this study focuses on the Nakhon Ratchasima HSR hub due to large GPP, municipality size, travel distance from the origin, ridership (number of HSR passengers), vacant land around the hub, and availability of feeder services [27]. However, the Thai government does not 
have practical know-how and experience in how to make it happen. This research uses international comparison to study the lesson learned from the best practice and outcome.

Japan is the best role model to generate TOD for sustainable development. Fukushima shinkansen station on the Tohoku shinkansen line is an optimal case study in Japan among others because it is similar in terms of station type, station size, travel distance, and travel time with Nakhon Ratchasima HSR hub [27]. Although the city policy and the surrounding area of the hub have the difference, we will ponder how to increase the potency before-after the operational HSR project.

\section{RESEARCH APPROACH DATA SOURCES}

\subsection{Research methodology}

The analysis was done by following the process depicted in Fig. 1. To begin, this study was identified the definition of the station catchment area for the HSR/shinkansen station. The representative HSR hub in Thailand was then assessed the importance of HSR hubs in terms of potential and necessity of development.

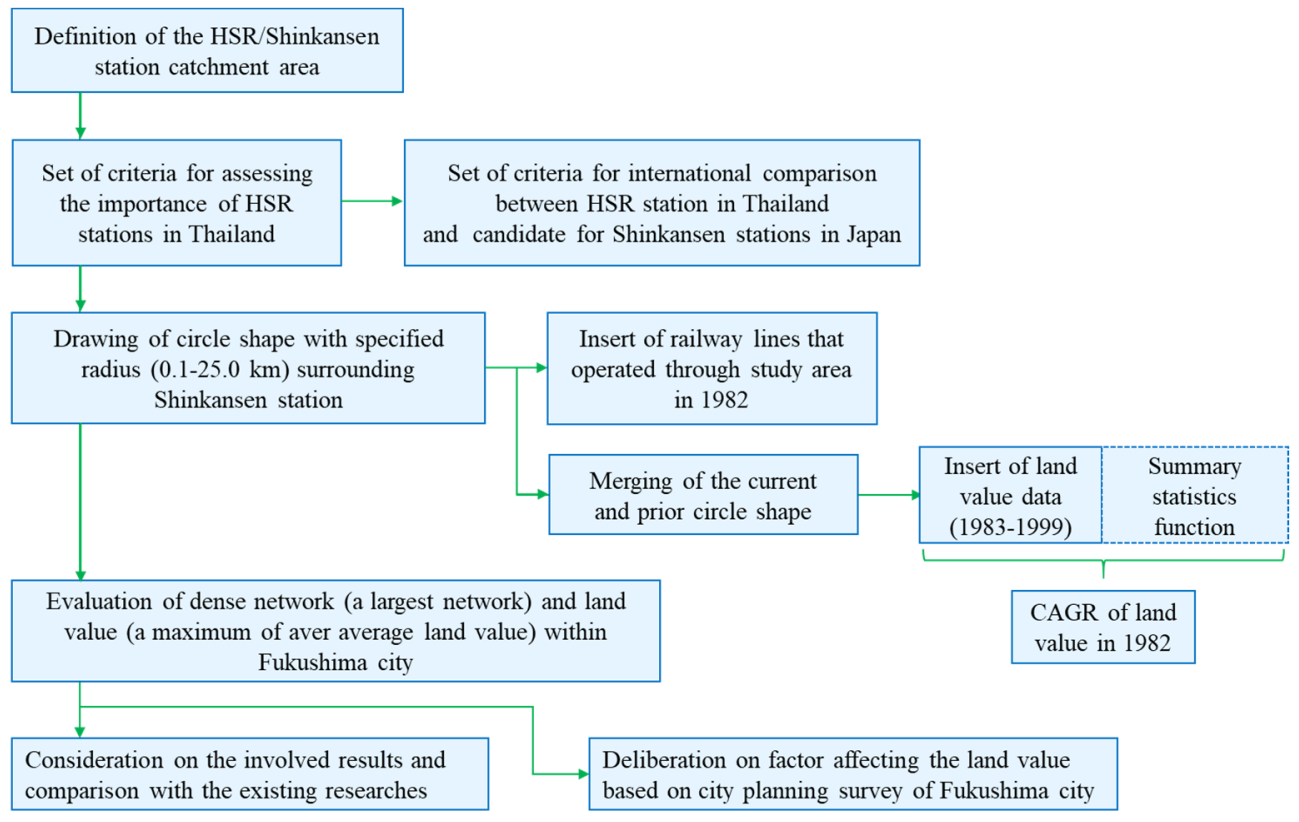

Figure 1: Process of analysis.

Following this, the representative HSR hub from Thailand was collated with the Japanese shinkansen stations by utilizing station type, station size, travel distance, and travel time because Japan was a famous and well-known TOD for its excellent mobility and sustainability. An international comparison was important for the HSR station catchment area in Thailand, where became the first developing country to invest and require to achieve sustainable development in the future. 
After that, for grasping what range was required to be developed about land use under the premise of the access by dense network and land value. ArcGIS software version 10.6.1 was used as a tool to overcome the station catchment area by setting origin (city center: Fukushima shinkansen station) and destination (boundary: Fukushima city).

According to Murakami and Cervero [7] and Zhong et al. [8], the reasonable $\mathrm{HSR} /$ shinkansen station catchment area falls in the radius range of 5-25 km because of the inter-city railway. The circle shape was drawn by a specific radius $(0.1-25.0 \mathrm{~km})$ surrounding Fukushima shinkansen station. In parallel, four railway networks (Abukuma express line, Tohoku mainline, lizaka line, and Ou main line) were inserted in the map which linked the Fukushima shinkansen station in 1982, including land value.

A dense network approach was proposed and applied for the evaluation of the Fukushima shinkansen station catchment area. On the other hand, this analysis examined the parameter that had the consistency of transport and land-use theory and had to cover long-term panel data; hence, the land value parameter was an alternative indicator to measure the station catchment area as well. This research looked more accurate than existing studies by using one decimal place of the circular surface.

However, the land value approach was a more sensitive process than the dene network perspective. After drawing a circle shape, this research merged the current and prior circle shape and then added the land value data (1983-1999), but it faced the incompleteness of the (data on) the Ministry of Land, Infrastructure, Transport and Tourism (MLIT) website in 1982. Therefore, the compound annual growth rate (CAGR) method was an alternative way to solve this point. Next, Arctoolbox was selected for the summary statistics function. Finally, the sizes of the Fukushima shinkansen station catchment areas were examined in two points of view and collated with the existing studies [7], [8]. Factor affecting the land value was then considered in each factor (population growth and economic growth (industry)) during 1975-1986 based on the basic survey of city planning in Fukushima city.

\subsection{Data sources}

The precise locations of Fukushima shinkansen station and other railway stations in Fukushima prefecture were obtained from the geographic information system (GIS) shapefile provided by e-stat and MLIT website. The GIS shapefile was produced by using online satellite imagery techniques [28].

This analysis did not attempt to estimate the land value change in Fukushima prefecture whether public policies might be able to harness and leverage these trends to induce greater land value benefits. This research used the actual data extracted from the MLIT website during 1983-2019, it faced limitations of data access, namely public investment in infrastructure, change in land-use regulation, and landowner's investment to test the factor affecting land value. Therefore, population and economic growth were considered and received from the basic survey of city planning in Fukushima city, Fukushima city hall.

\section{RESULT}

\subsection{HSR/Station catchment area}

5.1.1 The size of the Fukushima shinkansen station catchment area

Fukushima shinkansen station was imaged and connected Ou main line, lizaka line, and Abukuma express line in 1982. A dense network was $12.4 \mathrm{~km}$ from the city center based on $\mathrm{Ou}$ main line because of the largest network and primary feeder services within the 
boundary of the city. However, the travel distance depended on the feeder systems in different geographies. Therefore, we believed $12.4 \mathrm{~km}$ was a more reasonable radius for the Fukushima shinkansen station catchment area as illustrated in Fig. 2.

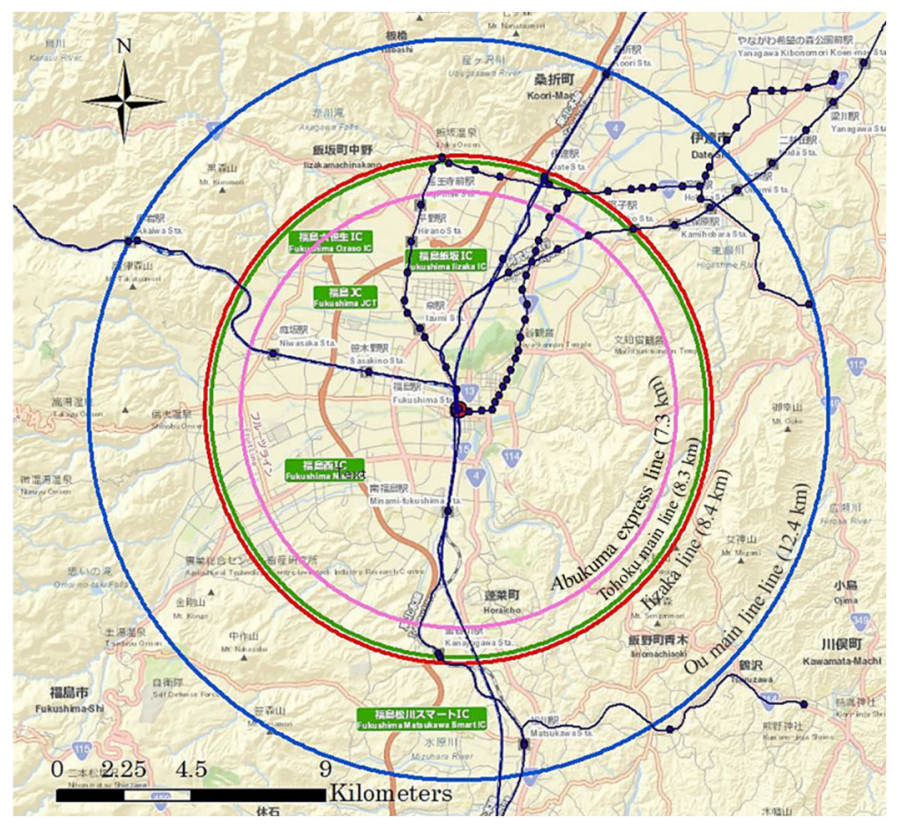

Figure 2: Fukushima shinkansen station catchment area in different feeder systems in 1982.

The Fukushima shinkansen station catchment area was simultaneously analyzed by using ArcGIS software with a maximum of average land value perspective during 19832019. CAGR method was selected to overcome an absence of historical data in the case of the first year of operation. Table 1 shows the relationship between the station catchment area of Fukushima shinkansen station and land value from 1982 to 1991. Fukushima shinkansen station catchment area was constant over time $(17.6 \mathrm{~km})$, but a maximum of average land value fluctuated between 162 and 165 Japanese yen $/ \mathrm{m}^{2}$. One reason might be the number of buildings declines in 1986.

From the above, the results illustrated that a radius of $12.4 \mathrm{~km}$ of the Fukushima shinkansen station catchment area captured a partial area of a radius of $17.6 \mathrm{~km}$ of the Fukushima shinkansen station catchment area in 1982 (or $70.45 \%$ ). These data appeared to suggest that the Fukushima shinkansen station had two layers of the station catchment area. In other words, the first area was the inner catchment area were had a dense network (12.4 $\mathrm{km}$ ), while the second area was the outer catchment area were had an impact from the inner catchment area $(17.6 \mathrm{~km})$ as can be seen in Fig. 3.

\subsubsection{Comparison of the prior HSR/shinkansen station catchment areas}

Table 2 shows the comparison of inner catchment areas among HSR hubs and HSR/ shinkansen lines. The results showed that a radius of $12.4 \mathrm{~km}$ of the Fukushima shinkansen 
Table 1: Relationship between Fukushima shinkansen station catchment area $(\mathrm{km})$ and a maximum of average land value $\left(\mathrm{JPY} / \mathrm{m}^{2}\right)$.

\begin{tabular}{|c|c|c|c|}
\hline Year & $\begin{array}{c}\text { Building } \\
\text { (unit) }\end{array}$ & $\begin{array}{c}\text { Fukushima shinkansen } \\
\text { station catchment area } \\
(\mathrm{km})\end{array}$ & $\begin{array}{c}\text { A maximum of } \\
\text { average land } \\
\text { value }\left(\mathrm{JPY} / \mathrm{m}^{2}\right)\end{array}$ \\
\hline 1982 & NA & 17.6 & 165 \\
\hline 1983 & 70 & 17.6 & 165 \\
\hline 1984 & 70 & 17.6 & 165 \\
\hline 1985 & 70 & 17.6 & 165 \\
\hline 1986 & 68 & 17.6 & 162 \\
\hline 1987 & 68 & 17.6 & 162 \\
\hline 1988 & 68 & 17.6 & 162 \\
\hline 1989 & 68 & 17.6 & 162 \\
\hline 1990 & 68 & 17.6 & 162 \\
\hline 1991 & 68 & 17.6 & \\
\hline
\end{tabular}

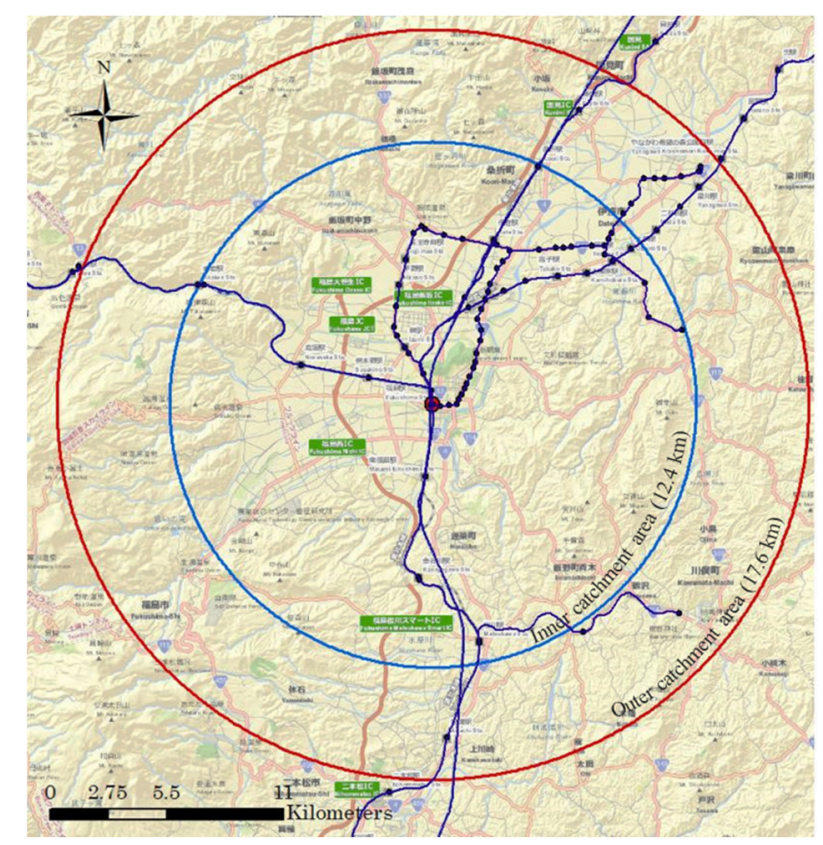

Figure 3: Inner and outer catchment area of Fukushima shinkansen station in 1982.

station was denser than a radius of $25 \mathrm{~km}$ of Californian cities (San Francisco Bay Area and Los Angeles), but less dense than a radius of $10 \mathrm{~km}$ of Spanish cities (Barcelona and Madrid) and a radius of $5 \mathrm{~km}$ of 17 cities of Tokaido shinkansen line, Northeast Corridor, and California HSR.

One of the main reasons was Fukushima city had the limitation of land to development and brought about population density based on the survey of city planning in Fukushima 
Table 2: Comparison of inner catchment areas.

\begin{tabular}{|l|c|c|c|c|}
\hline $\begin{array}{l}\text { HSR hub/HSR line/ } \\
\text { shinkansen line }\end{array}$ & $\begin{array}{c}\text { Station } \\
\text { catchment } \\
\text { area }(\mathrm{km})\end{array}$ & $\begin{array}{c}\text { Population } \\
\text { (million persons) }\end{array}$ & $\begin{array}{c}\text { Area } \\
\left(\mathrm{km}^{2}\right)\end{array}$ & $\begin{array}{c}\text { Population } \\
\text { density } \\
\left.\text { (persons } / \mathrm{km}^{2}\right)\end{array}$ \\
\hline Barcelona & 10.0 & 4.96 & 7,733 & 641.4 \\
\hline Madrid & 10.0 & 6.45 & 8,030 & 803.2 \\
\hline San Francisco Bay area & 25.0 & 6.17 & 13,527 & 456.2 \\
\hline Los Angeles & 25.0 & 17.30 & 30,783 & 562.0 \\
\hline Fukushima & 12.4 & $0.29^{*}$ & 768 & 377.6 \\
\hline Tokaido shinkansen line & 5.0 & NA & NA & NA \\
\hline Northeast Corridor & 5.0 & NA & NA & NA \\
\hline California HSR & 5.0 & NA & NA & NA \\
\hline
\end{tabular}

Note: *Using the CAGR during 1975-1980.
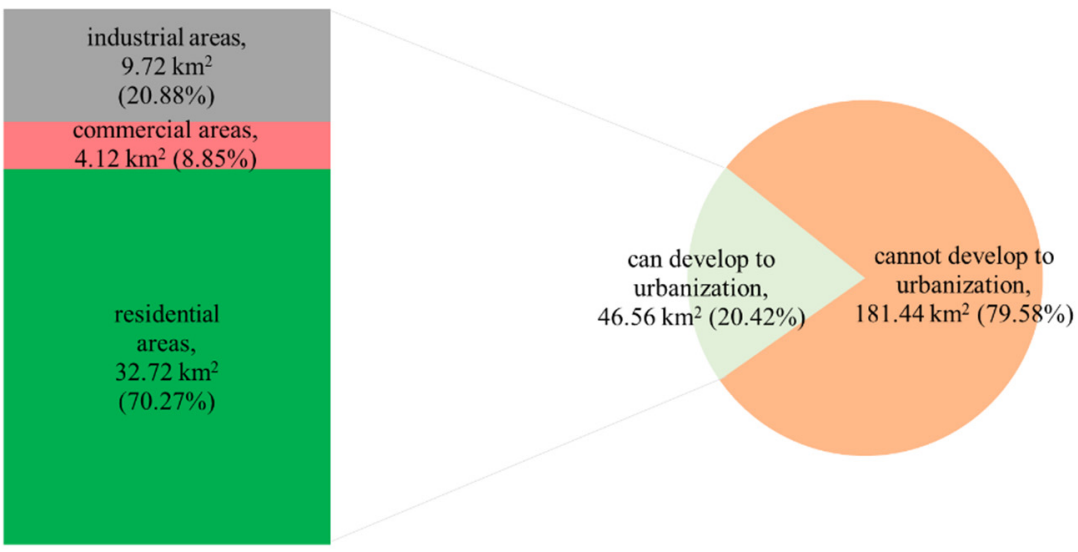

Figure 4: Ratio of land-use where can and cannot develop to urbanization.

city in 1982. It had less area to develop urbanization $\left(46.56 \mathrm{~km}^{2}\right)$. This area consisted of residential areas $\left(32.72 \mathrm{~km}^{2}\right)$, commercial areas $\left(4.12 \mathrm{~km}^{2}\right)$, and industrial areas $\left(9.72 \mathrm{~km}^{2}\right)$. In contrast, there were $181.44 \mathrm{~km}^{2}$ of an area where could not develop to urbanization, whereas it was covered with forests, mountains, and agricultures (see Fig. 4).

\subsubsection{Effect of land use and characteristics}

The residential areas were the most preferred development as $53.85 \%$ of the ratio of landuse between 1980 and 1985 in Fig. 4. The mixture of residential and commercial areas accounted for $15.90 \%$ and was the second-ranking. At the same time, this research took into account the area surrounding Fukushima shinkansen station by a site visit. The result clearly illustrated that a radius of $6-8 \mathrm{~km}$ from the Fukushima shinkansen station was consistent with the past. Most of them are residential areas (hotels, apartments, and houses), but the commercial areas (plazas, convenience stores, and supermarkets) are quite a few.

Likewise, this research took into account around Fukushima shinkansen station and other shinkansen stations, e.g., Hakata shinkansen station, Nagoya shinkansen station, and Yokohama shinkansen station. These results appeared to contradict the above view that 
mainly established for commercial use, for instance, the local commercial street around station, plazas, and offices. The results perhaps led to alternative urban economic scenarios as well as urban structure formulation in each city.

However, land use surrounding the Fukushima shinkansen station was developed by using phasing investment. This issue possibly led to a limitation of the circle surface method because it could not take the geographical area surrounding the Fukushima shinkansen station into account for reality.

\subsection{Factor affecting land value and attribution}

\subsubsection{Population}

As Japanese housing and land survey from the Ministry of Internal Affairs and Communications during 1998-2003, the results indicated that the acquisition of land and housing was among people aged 15-64 years old. Meanwhile, the largest number of populations in Fukushima city by age group was consistent with the above results (or $67.79 \%$ per year) during $1975-1985$ as illustrated in Fig. 5.

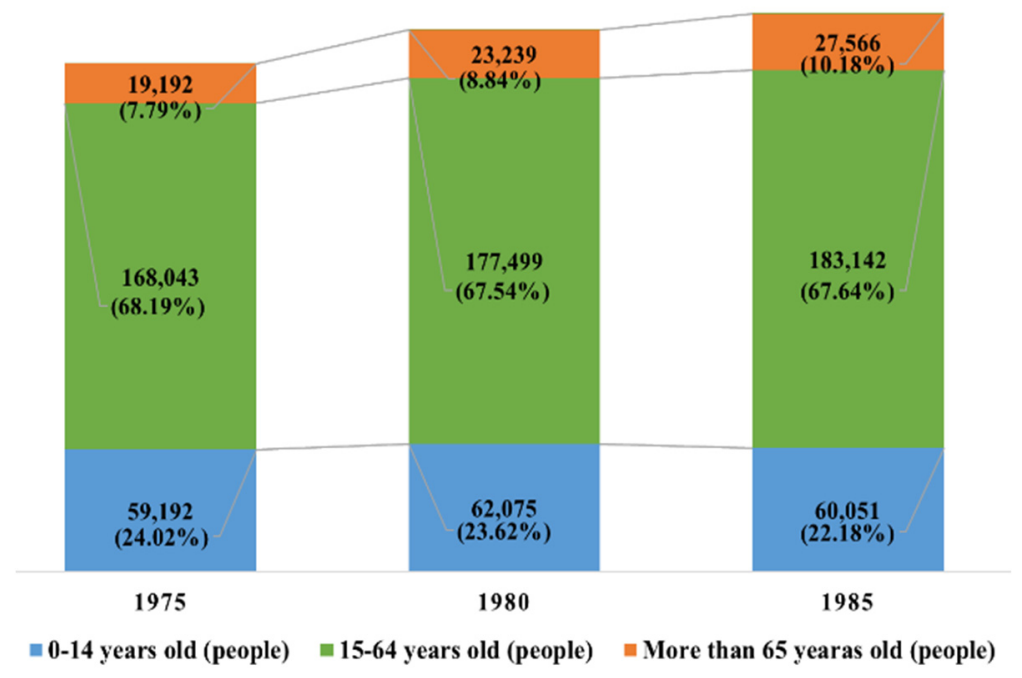

Figure 5: Population by age group.

Next, this research examined the population pyramid from 1975 to 1985 by the 5 year age group. The children's generation was gradually declining, but the elderly population was moderately grown. Therefore, it was possible to read the direction of the transition from 1975 by age group. The results presented in Fig. 5 displayed that the number of children decreased by $0.76 \%$ per year. In the case of the working-age population, it slightly grew thanks to a second baby boom since the 1970s.

Furthermore, this research collated the CAGR of the population during 1975-1985 with the land value from 1982 to 1985 (see Table 3). The results indicated that the CAGR of population and CAGR of land value was a parallel way (positive value). Hence, the population factor could affect the land value in the initial phase (1982-1985). Because the population was a demand for land and influenced the change in land use. In other words, an increase in demand for land use led to an increase in rent or buy or sell [15], [23]. 
Table 3: Population (people) and land value $\left(\mathrm{JPY} / \mathrm{m}^{2}\right)$.

\begin{tabular}{|c|c|c|}
\hline Year & Population & Land value \\
\hline 1975 & 246,427 & NA \\
\hline 1980 & 262,812 & NA \\
\hline 1982 & NA & 162.93 \\
\hline 1983 & NA & 165.16 \\
\hline 1984 & NA & 165.16 \\
\hline 1985 & 270,759 & 165.14 \\
\hline CAGR (\%) & 0.97 & 0.45 \\
\hline
\end{tabular}

\subsubsection{Economics}

The population was changed in Fukushima city during 1975-1985 because of a decline in birth rate, an increase of the elderly population, and productivity improvement, including technological innovation as a key for the Japanese economy. However, it was difficult to elucidate the main factors for economic growth.

Regarding the empirical studies, the development of HSR/shinkansen projects generated a significant impact on urban service industry agglomeration with fast flows of factor resources [29], [30]. Besides, Japan's industry structure (such as Fukushima city) shifted industrial structure from heavy industry to tertiary industry after World War II owing to a change in social structure issues as illustrated in Table 4.

Table 4: Number of employees (thousand people).

\begin{tabular}{|l|c|c|c|}
\hline Year & Primary industry* & Secondary industry** & Tertiary industry*** \\
\hline 1975 & 285 & 35,484 & 65,563 \\
\hline Ratio (\%) & 0.28 & 35.02 & 64.70 \\
\hline 1978 & 522 & 35,888 & 73,181 \\
\hline Ratio (\%) & 0.48 & 32.75 & 66.78 \\
\hline 1981 & 557 & 37,730 & 86,757 \\
\hline Ratio (\%) & 0.45 & 30.17 & 69.38 \\
\hline 1986 & 479 & 38,789 & 92,919 \\
\hline Ratio (\%) & 0.36 & 29.34 & 70.29 \\
\hline Average & 460.75 & $36,972.75$ & $79,605.00$ \\
\hline CAGR (\%) & 9.05 & 0.88 & 3.83 \\
\hline
\end{tabular}

Notes: *Primary industry: agriculture, forestry, and fishing; **Secondary industry: mining, manufacturing, and construction; ***Tertiary industry: wholesale and retail trade, transport and postal services, accommodation and food service activities, information and communications, finance and insurance, real estate, professional, scientific and technical activities, public administration, education, human health and social work activities, and other service activities.

The primary industry was involved in the collection of resources in nature. The secondary industry was related to processing the collected resources. The tertiary sector was concerned with providing services other than the aforementioned activities. Therefore, we conformed to the empirical research that the impact looked at coming to the trend in the industrial structure.

According to the number of employees, the tertiary industry was the major industry and had 79,605 thousand people (or $68.02 \%$ per market share). The wholesale and retail trade 
sector ranked first. It employed 32,735 thousand people per year, following by the service sector and manufacturing sector.

In the meantime, Table 5 shows the number of offices by major groupings. A tertiary industry was the main industry and had $10,390.50$ houses (or $82.71 \%$ of market share). The service sector and electricity, gas, water supply, and heat supply sector in the tertiary industry were the first rank and second rank because of one of the main industries in Fukushima prefecture. These results presumably led to GPP in Fukushima prefecture. It was clear from a macroeconomic point of view that GPP grew a little from $1.47 \%$ in 1975 to $1.50 \%$ in 1982 (or $0.30 \%$ per year).

Table 5: Number of offices (houses).

\begin{tabular}{|l|c|c|c|}
\hline Year & Primary industry & Secondary industry & Tertiary industry \\
\hline 1975 & 34 & 1,931 & 9,319 \\
\hline Ratio (\%) & 0.30 & 17.11 & 82.59 \\
\hline 1978 & 38 & 2,027 & 9,788 \\
\hline Ratio (\%) & 0.32 & 17.10 & 82.58 \\
\hline 1981 & 58 & 2,217 & 10,896 \\
\hline Ratio (\%) & 0.44 & 16.83 & 82.73 \\
\hline 1986 & 43 & 2,342 & 11,559 \\
\hline Ratio (\%) & 0.31 & 16.80 & 82.90 \\
\hline Average & 43.25 & $2,129.25$ & $10,390.50$ \\
\hline CAGR (\%) & 5.43 & 1.97 & 2.22 \\
\hline
\end{tabular}

Table 6 shows the CAGR of the number of offices (houses) and land value during 19751986. The results indicated that the CAGR of the number of primary industries, secondary industry, and tertiary industry and CAGR of land value was a parallel way (positive value). Hence, the number of offices factor could affect the land value in the initial phase (19821986). Because the development of HSR/shinkansen resulted in a change in accessibility for industries and residential catchment areas as well as a reduced generalized cost. In addition, land value resulted from changes in accessibility that drove the value uplift from transport investment and created the opportunity for enhanced economic activities [15][23].

Table 6: Number of offices (houses) and land value $\left(\mathrm{JPY} / \mathrm{m}^{2}\right)$.

\begin{tabular}{|c|c|c|c|c|}
\hline Year & $\begin{array}{c}\text { Primary } \\
\text { industry }\end{array}$ & $\begin{array}{c}\text { Secondary } \\
\text { industry }\end{array}$ & $\begin{array}{c}\text { Tertiary } \\
\text { industry }\end{array}$ & Land value \\
\hline 1975 & 34 & 1,931 & 9,319 & NA \\
\hline 1978 & 38 & 2,027 & 9,788 & NA \\
\hline 1981 & 58 & 2,217 & 10,896 & NA \\
\hline 1982 & NA & NA & NA & 162.93 \\
\hline 1983 & NA & NA & NA & 165.16 \\
\hline 1984 & NA & NA & NA & 165.16 \\
\hline 1985 & NA & NA & NA & 165.14 \\
\hline 1986 & 43 & 2,342 & 11,559 & 165.15 \\
\hline CAGR $(\%)$ & 5.43 & 1.97 & 2.22 & 0.34 \\
\hline
\end{tabular}




\section{CONCLUSION}

HSR investment in Thailand is not feasible, but when it utilizes land development surrounding HSR hubs, the economic benefits increase and fit the benchmark. However, the Thai government does not have the practical know-how and experience in how to make it happen. This research determines to study from the lesson learned from Japan, whereas it is the best land development for sustainability.

This research uses the international comparison between a representative HSR station in Thailand and the candidate for Japanese shinkansen stations by using the criteria. Then we highlight how to evaluate the Fukushima shinkansen station catchment area based on dense network and land value approach. Because station catchment area is a vital factor to balance demand and supply of public transportation systems and relates to the land value and floor area ratio.

The present study endeavors to assess the size of the Fukushima shinkansen station catchment area when it was operated in 1982. As a case study, we draw a tentative outlook of the station catchment area surrounding Fukushima shinkansen station in terms of railway routes and land value by using ArcGIS software. In the meantime, drawing of circle surface on the ArcGIS map is a fairly good way for examining the inter-city railway, but it does not take the geography into account when the area developed at a different time as well as we cannot grasp the natural obstacle within the station catchment area.

Regarding the result, the radius of the Fukushima shinkansen station catchment area is 12.4 and $17.6 \mathrm{~km}$ based on dense network and land value approach, respectively. On the whole, the Fukushima shinkansen station has two layers of station catchment areas which consisted of the inner catchment area were had a large network $(12.4 \mathrm{~km})$ and primary feeder service within the Fukushima city boundary and the outer catchment area were had an impact from the inner catchment area $(17.6 \mathrm{~km})$. Since Fukushima city has a limitation of land to develop for urbanization, station catchment area beats only California cities. The specific result from the case study may not provide all factors affecting land value that influenced change in land value because of lack of sufficient data, namely public investment in infrastructure, change in land-use regulation, and landowner's investment. For these reasons, we consider only the population and economic factors. The population, primary industry, secondary industry, and tertiary factor are a significant impact on land value from a macro point of view.

These results bring about some interesting directions for future research. Further study is hence needed to determine the multi-dimensional factors affecting travelers to access the Nakhon Ratchasima HSR hub within the station catchment area. The research outcomes, we expect to grasp the needs and design the fundamental facilities about TOD to increase people's mobility and accessibility.

This study may be useful for developing countries to analyze the station catchment area and developing an appropriate policy relating to the improvement catchment area on HSR/shinkansen stations to make the catchment area more attractive, beneficial, and sustainable as well as consider the feeder systems and level of service for the travelers in the future.

\section{ACKNOWLEDGEMENT}

The authors would like to express our sincere gratitude and appreciation to Mr. Watanabe Hiroshi for providing the basic survey of city planning in Fukushima city. 


\section{REFERENCES}

[1] Tissayakorn, K., Nakamura, F., Tanaka, S. \& Miura, S., A study on the barriers of the Thai government for development of high speed rail project. Journal of the Eastern Asia Society for Transportation Studies, 13, pp. 555-573, 2019.

[2] The Office of the National Economic and Social Development Council, Guidelines and Criteria of Project Analysis. https://www.nesdc.go.th/ewt_w3c/ewt_dl_link.php ?nid=3120. Accessed on: 5 Jan. 2021.

[3] Chalermpong, S. \& Ratanawaraha, A., Guidelines for Legislation and Regulation Improvements to Support Transit-Oriented Development in Thailand. Chulalongkorn University, 2016.

[4] Vuchic, V.R., Urban Transit: Operations, Planning, and Economics, John Wiley \& Sons, 2005.

[5] Duany, A. \& Talen, E., Transect planning. Journal of the American Planning Association, 68, pp. 245-266, 2007.

[6] Catz, S.L. \& Christian, A., Thinking ahead: High-speed rail in Southern California. Paper Prepared for the Institute of Transportation Studies at the University of California Irvine, 2010.

[7] Murakami, J. \& Cervero, R., High-Speed rail and economic development: Business agglomerations and policy implications. University of California Transportation Center, 2012.

[8] Zhong, C., Bel, G. \& Warner, M.E., High-speed rail accessibility: A comparative analysis of urban access in Los Angeles, San Francisco, Madrid, and Barcelona. European Journal of Transport and Infrastructure Research, 14, pp. 468-488, 2014.

[9] Calthorpe, P., The Next American Metropolis: Ecology, Community, and the American Dream, Princeton, 1993.

[10] Cervero, R. \& Kockelman, K., Travel demand and the 3Ds: Density, diversity, and design. Journal of Transportation Research Part D: Transport and Environment, 2, pp. 199-219, 1997.

[11] Oh, J., Kwon, Y.J., Kim, Y., Terabe, S. \& Tomari, N., International comparison on high-Speed railway impacts and station area development: Japan, Taiwan and Korea. 2013-2015 KOTI-EASTS Special Research Project Report, 2015.

[12] Loo, B.P.Y., Chen, C. \& Chan, E.T.H., Rail-based transit-oriented development: Lessons from New York city and Hong Kong. Journal of Landscape and Urban Planning, 97, pp. 202-212, 2010.

[13] Sung, H. \& Oh, J., Transit-oriented development in a high-density city: Identifying its association with transit ridership in Seoul, Korea. Journal of Cities, 28, pp. 70-82, 2011.

[14] Dittmar, H. \& Ohland, G., The New Transit Town. Best Practices in Transit-Oriented Development. Island Press: Washington, DC, 2004.

[15] Suzuki, H., Murakami, J., Hong, Y.H. \& Tamayose, B., Financing Transit-Oriented Development with Land Values: Adapting Land Value Capture in Developing Countries, World Bank Group, 2015.

[16] Campos, J. \& de Rus, G., Some stylized facts about high-speed rail: A review of HSR experiences around the world. Transport Policy, 16(1), pp. 19-28, 2009.

[17] Giannopoulos, G.A. \& Boulougaris, G.A., Definition of accessibility for railway stations and its impact on railway passenger demand. Journal of Transportation Planning and Technology, 13, pp. 111-120, 1989. 
[18] Upchurch, C., Kuby, M., Zoldak, M. \& Barranda, A., Using GIS to generate mutually exclusive service areas linking travel on and off a network. Journal of Transport Geography, 12, pp. 23-33, 2004.

[19] Jun, M.J., Choi, K., Jeong, J.E., Kwon, K.H. \& Kim, H.J., Land-use characteristics of subway catchment areas and their influence on subway ridership in Seoul. Journal of Transport Geography, 48, pp. 30-40, 2015.

[20] Guerra, E., Cervero, R. \& Tischler, D., Half-mile circle: Does it best represent transit station catchments. Journal of the Transportation Record, 2276, pp. 101-109, 2012.

[21] Bowes, D.R. \& Ihlanfeldt, K.R., Identifying the impacts of rail transit stations on residential property values. Journal of Urban Economics, 50, pp. 1-25, 2001.

[22] Hansen, W.G., How accessibility shapes land-use. Journal of the American Institute of Planners, 25, pp. 73-76, 1959.

[23] Alonso, W., Location and Land-Use: Toward a General Theory of Land Rent, Harvard University Press: Cambridge, MA, 1964.

[24] Goldberg, M.A., Transportation, urban land values, and rents: A synthesis. Journal of Land Economics, 46, pp. 153-162, 1970.

[25] Litman, T., Evaluating accessibility for transportation planning: Measuring people's ability to reach desired goods and activities. Victoria Transport Policy Institute, 2012.

[26] Japan International Cooperation Agency, Nippon Koei Co., Ltd, Kisho Kurokawa Architect \& Associates \& UR Linkage Co., Ltd, Data Collection Survey on Urban Redevelopment in Bang Sue Area in the Kingdom of Thailand. Final Report, 2017.

[27] Tissayakorn, K., Nakamura, F., Tanaka, S. \& Miura, S., Measuring the impact of economic development on Fukushima shinkansen station investment. Proceedings of 2019 International Conference Asia-Pacific Planning Societies, 2019.

[28] Monkkonen, P., Using online satellite imagery as a research tool: Mapping changing patterns of urbanization in Mexico. Journal of Planning Education and Research, 28, pp. 225-236, 2008.

[29] Han, J., Hayashi, Y., Jia, P. \& Yuan, Q., Economic effect of high-speed rail: Empirical analysis of Shinkansen's impact on industrial location. Journal of Transportation Engineering, 138, pp. 1551-1557, 2012.

[30] Ren, J., A study of how high-speed railway affects county industry development. Journal of Social Sciences, 5, pp. 69-80, 2018. 